\title{
New Strategy for the Future of UNESCO
}

The United Nations Educational, Scientific and Cultural Organization (UNESCO)'s new strategy for the future will be built on its three main pillars of education, science, and culture, and will follow two main lines of action - concentration of objectives, and dialogue-according to a statement by the incoming Director-General of the Organization, Professor Federico Mayor, during a press conference on 16 May 1988 in Paris, held on the eve of the Executive Board's 129th Session (25 May to 9 June), which would discuss the outlines of UNESCO's Third Mediumterm Plan.

Professor Mayor indicated that the document he would be submitting to the 51 Members of the Board 'is a draft designed to provoke, and should stimulate a major debate'. $\mathrm{He}$ announced that he was proposing to reduce the number of major programmes from fourteen to five, and the programmes from sixty to sixteen. This concentration of objectives, he said, would be accompanied by wide-ranging consultations with the other agencies of the United Nations system, with intergovernmental organizations, and also with nongovernmental organizations (NGOs) which represented for UNESCO an extraordinary treasure of intellectual potential. He went on to say that by mid-June a first draft of the medium-term plan would be circulated widely among educators, university heads, artists, journalists, and other intellectuals, with the aim of coming up with new approaches and novel ideas.

\section{Mission of Peace}

The Director-General said that the main goal was to fulfil UNESCO's mission of peace-'peace among men, peace between the human community and its ecological environment' - guided by dignity, solidarity, and efficiency. He emphasized action in favour of developing countries, saying that this involved building up human resources through a major programme promoting access to knowledge and training. UNESCO, he stressed, needed to strengthen its presence in the field alongside the other United Nations agencies. Its regional network should be substantially modified to arrive at improved understanding of the needs of the developing countries, and to set up good projects that were likely to respond to the concerns of those countries.

\section{Austerity Measures}

Referring to the Organization's budgetary situation, to be examined by the Executive Board, the Director-General reviewed the austerity measures which had already resulted in a 50\% reduction in the volume of documentation and a $25 \%$ cut in the number and length of meetings and missions. He indicated that he will propose further economy measures which could lead to more resources being available for really meaningful activities. He announced that a major reorganization would take place as soon as the main lines of UNESCO's future action had been decided.

UNESCO INFORMATION SERVICE 7 Place de Fontenoy 75700 Paris

France.

\section{Nature Tourism}

Every year, more and more international tourists steer away from the traditional European or other tour and go for the exotic-a Nature adventure in a developing country. Some US $\$ 25$ thousand millions per year is transferred in this way from North to South - a figure that is beginning to attract the interest of government planners.

Kenya, Ecuador (for its Galápagos Islands), and Costa Rica, are three countries which trade on their abundant natural riches to attract tourists and, in doing so, have placed new importance on conservation. Costa Rica, with its high species-diversity -850 species of birds, for example-and extensive protected areas (more than 25\% of Costa Rica is protected to some degree), has recently entered the Nature tourism market and is already experiencing substantial success.

According to Michael Kaye, owner of the largest Naturetour agency in Costa Rica, 'We had $46 \%$ growth in 1986 , and it looks as though we did even better in 1987'. Kaye runs river-rafting trips, 'a day with a naturalist' trips, and sport fishing trips. His business, as with all Nature tour operators, is heavily dependent on the natural resourcebase of Costa Rica. Deforestation, sedimentation, and pollution, can keep tourists away and affect his profits. Unfortunately, the annual deforestation rate for Costa Rica is a high $3.9 \%$, while about $17 \%$ of the country is seriously eroded. With a threat to livelihoods apparent, it is not at all surprising to find tour operators, such as Sergio Miranda, taking steps to control damage to the environment.

Miranda has seen his private reserve area threatened by slash-and-burn agriculturalists. He is fighting back by developing and implementing a management plan for lands adjoining his reserve. He identifies an old problem: 'Biologists have no money. Money has no environmental awareness.' His hope is to combine money and conserva- tion-to make it very clear that conservation puts money into pockets.

Tourism is currently the number three foreign-exchange earner in Costa Rica - nearly US \$138 millions in 1986 . What many tourists want to see are the very lands which are being lost to agriculture or erosion, and that point is not lost on the Costa Rican Government. The Government is hard at work trying to manage essential natural resources so as to ensure long-term economic development. More than that, the commitment of the Government to Costa Rica's natural resources is seen in its planning to develop a National Conservation Strategy, a component of which will be Nature tourism for both Costa Ricans and foreigners. This could be anything from fishing to tourism in Costa Rica's impressive cloud forests. Costa Ricans believe that well-managed natural areas can bring a continuing cashflow to their country, and while that isn't the only reason given to save natural areas, it is a powerful incentive.

At one time, conservation motives were questioned by the very people who might benefit most by their implementation. Now in Costa Rica, at least, that time appears to have passed. The relationship between Nature tourism and conservation is perhaps best expressed by Amos Bien, director of a Nature tour company. 'Nobody', he says, 'is going to cut down a rain-forest - which is a heluva lot of work - if they can make more money by not cutting it down.' Nature tour operators in Costa Rica are now banking on the latter.
HORTENSE WHELAN c/O IUCN/UICN Avenue du Mont-Blanc 1196 Gland Switzerland. 